\title{
Stromal Valvular Proliferation
}

National Cancer Institute

\section{Source}

National Cancer Institute. Stromal Valvular Proliferation. NCI Thesaurus. Code C139161.

A finding indicating proliferation of the stromal valvular cells 